\title{
Effect of feed restriction on performance of growing rabbits
}

\author{
Maria Cristina de Oliveira ${ }^{1}$, Rossane Pereira da Silva ${ }^{2}$, Liomar Sousa Araújo ${ }^{2}$, Valdevino \\ Rodrigues da Silva ${ }^{2}$, Elis Aparecido Bento ${ }^{3}$, Diones Montes da Silva ${ }^{4}$
}

\author{
${ }^{1}$ Faculdade de Medicina Veterinária, Universidade de Rio Verde, Rio Verde, GO, Brasil, 75901-910. \\ 2 Graduando de Zootecnia, IFGoiano, Rio Verde, GO, Brasil. \\ ${ }^{3}$ Departamento de Zootecnia, IFGoiano, Rio Verde, GO, Brasil. \\ ${ }^{4}$ Graduando de Medicina Veterinária, Faculdade de Medicina Veterinária, Universidade de Rio Verde, Rio Verde, GO, Brasil.
}

ABSTRACT - This experiment assessed the effect of feed restriction in rabbits on performance and economic viability of the activity. Sixty New Zealand White rabbits, weaned at 33 days and slaughtered at 81 days of age, were used. The design was of randomized blocks with four treatments and five replications. The treatments were, as follows: 1 - free feeding, 2 feed restriction from 35 to 40 days of age ( $50 \mathrm{~g} / \mathrm{d} / \mathrm{rabbit}), 3$ - feed restriction from 54 to 61 days of age (90 g/d/rabbit) and 4 - feed restriction from 33 to 40 days ( $50 \mathrm{~g} / \mathrm{d} /$ rabbit) and from 54 to 61 days of age ( $90 \mathrm{~g} / \mathrm{d} / \mathrm{rabbit}$ ). There was no difference in the performance and carcass parameters, indicating that there was compensatory growth in the rabbits that suffered feed restriction. The best gross margin was obtained with feed restriction from 54 to 61 days age. Feed restriction in growing rabbits can be adopted at different ages because it does not interfere negatively in the performance and carcass parameters. In two periods and from 51 to 61 days, feed restriction was more economically viable for the sale of live and slaughtered rabbits, respectively.

Key Words: animal nutrition, compensatory growth, economic viability

\section{Introduction}

Feed for growing rabbits is rationed to reduce the incidence of enteropathies that lead to animal losses. Nevertheless, feed restriction can be used at different periods (usually from one to three weeks after weaning) or at different levels (restriction percentage in relation to free intake) (Di Meo et al., 2007). Feed restriction suppresses growth during the restriction period, but the growth reduced can be compensated with greater future intake (Govaerts et al., 2000).

During feed restriction, there may be increase in feed efficiency (Tumová et al., 2002; Dalle Zotte et al., 2005) and improved nutrient digestibility (Tumová et al., 2003; Di Meo et al., 2007). However, carcass characteristics are factors to consider when assessing alternative feeding programs.

According to Ledin (1984), carcass characteristics are not influenced by restriction. Tumová et al. (2003) reported that feed restriction did not affect weight (BW) or carcass yield and that rabbits that received restricted feed for three weeks had lower BW than the group restricted for one or two weeks, although yield was not influenced by the feeding regimen. The gastrointestinal tract is longer in the restricted animals, which might explain in part reduction in the carcass yield (Cantier et al., 1969).

Tumová et al. (2002) observed in rabbits in feed restriction from 35 to 42 days ( $50 \mathrm{~g} / \mathrm{d} / \mathrm{rabbit}$ ) and from 40 to 49 days of age ( $65 \mathrm{~g} / \mathrm{d} / \mathrm{rabbit})$ that their daily weight gain (DWG) decreased during restriction and the DWG in restricted rabbits was from 600 to $700 \mathrm{~g} / \mathrm{d} /$ rabbit body weight lower than that of non-restricted animals. However, in the week following the restriction, the DWG was greater by $400 \mathrm{~g} / \mathrm{kg}$ body weight in the restricted animals than in the rabbits fed freely and thus compensatory growth resulted in significant differences in the body weight at the end of the experiment.

Regarding the weight of the organs and the edible viscera, Tumová et al. (2006) observed that during feed restriction, kidney and liver weight decreased in the rabbits under restriction, but in the first week of free feeding, there was no difference compared with the rabbits that received free feeding. It is assumed that in re-feeding, priority is given to the development of the internal organs that grow more quickly than the other parts of the body.

The present study assessed the effects of feed restriction on growing rabbit performance, carcass and edible viscera weights and economic viability. 


\section{Material and Methods}

The experiment was carried out in the Rabbit Sector of Centro Federal de Educação Tecnológica in Rio Verde, Goiás, Brazil, from January to August 2008, using 60 New Zealand White rabbits, initial mean weight $636.76 \pm 13.28 \mathrm{~g}$, weaned at 33 days and slaughtered at 81 days of age. A randomized block design was used with four treatments and five replications. The blocks were conducted at different times and each block was formed by one replication of each treatment. The treatments were as follows 1 - free feeding, 2 - feed restriction from 35 to 40 days of age ( $50 \mathrm{~g} / \mathrm{d} / \mathrm{rabbit})$, 3 - feed restriction from 54 to 61 days of age ( $90 \mathrm{~g} / \mathrm{d} / \mathrm{rabbit})$ and 4 - feed restriction from 33 to 40 days ( $50 \mathrm{~g} / \mathrm{d} /$ rabbit) and from 54 to 61 days of age ( $90 \mathrm{~g} / \mathrm{d} / \mathrm{rabbit})$. The rabbits fed freely at all other times.

The rearing system was in open air and the animals were kept in groups of three (two females and one male) in cages with masonry sides, measuring $0.80 \times 0.75 \times 0.67 \mathrm{~m}$ (length $\times$ width $\times$ height), equipped with ceramic feeding trough and drinking fountain. Water was supplied ad libitum and the commercial pelleted feed $(170 \mathrm{~g} / \mathrm{kg}$ crude protein, $150 \mathrm{~g} / \mathrm{kg}$ crude fiber, $20 \mathrm{~g} / \mathrm{kg}$ Ca, $7.5 \mathrm{~g} / \mathrm{kg}$ P, $9.4 \mathrm{~g} / \mathrm{kg}$ lysine and $6.3 \mathrm{~g} / \mathrm{kg}$ metionine + cysteine and $2300 \mathrm{kcal} / \mathrm{kg}$ digestible energy) was supplied according to the feeding regimen of each treatment.

Animals and the diets were weighed at the start and end of the experimental period to calculate the daily weight gain, feed intake and feed conversion. After the final weighing, animals were fasted for 12 hours and then weighed again to obtain the weight at slaughter, which served as reference to calculate the relative carcass weight. After slaughter and evisceration, head and feet were removed and the carcass was obtained and weighed 15 minutes after slaughter. The edible viscera were then weighed and their relative weights were determined in function of the carcass weight.

The economic viability was calculated considering the mean selling values of live rabbits for slaughter $(\mathrm{R} \$ 7.50 / \mathrm{kg})$ and the feed value $(\mathrm{R} \$ 0.92 / \mathrm{kg})$. The gross margin was obtained from the difference between the gross profit (live animal weight $\times \mathrm{R} \$ 7.50$ or carcass weight $\times \mathrm{R} \$ 12.00$ ) and the feed cost (weight of feed ingested $\times \mathrm{R} \$ 0.92$ ). The prices were obtained from the Rabbit Raisers Association in Brasília on 04/06/2011.

The results were submitted to analysis of variance using the software SAEG (Sistema para Análises Estatísticas, version 9.1) and the means were compared by the Tukey test with $\alpha=0.05$.

\section{Results and Discussion}

There was no difference $(\mathrm{P}>0.05)$ in the rabbit productive performance (Table 1 ) due to feed restriction. The reason why there was no difference was because rabbits under feed restriction grew more quickly than normal after the restriction period, equaling the body weight (BW), daily weight gain (DWG), daily feed intake (DFI) and feed conversion (FC) at the end of the experimental period. In addition to inducing compensatory growth, feed restriction also improved feed efficiency (Dalle Zotte et al., 2005) and increased the gastrointestinal tract length (Cantier et al., 1969), which explained the results obtained.

In monogastric animals, compensatory growth is more related to the tissues that are not part of the carcass. Researchers have studied nitrogen retention in pigs when there was large ingestion of this nutrient followed by low ingestion and suggested that these results were associated mainly with restoring the labile nitrogen stocks in the skin, viscera and blood. It is assumed that compensatory growth disappears when the nitrogen stocks are replaced (Lawrence \& Fowler, 2002).

Di Meo et al. (2007) studied the effects of free feeding and feeding restricted to $900 \mathrm{~g} / \mathrm{d} /$ rabbit of the free intake for growing rabbits from 35 to 84 day of age, and observed that there was no difference in the DWG and BW results, but the DFI was $111 \mathrm{~g} / \mathrm{kg}$ lower and the FC was better in restricted rabbits (3.40) compared with those that were fed freely (3.88). Yakubu et al. (2007) studied the effects of feed restriction on weaned rabbits during five weeks. The rabbits received feed ad libitum or were fed only for eight hours/day or in

Table 1 - Productive performance of growing rabbits at 81 days of age subjected or not to feed restriction

\begin{tabular}{|c|c|c|c|c|c|c|}
\hline \multirow[b]{2}{*}{ Parameters } & \multicolumn{4}{|c|}{ Treatments } & \multirow[b]{2}{*}{$\mathrm{P}$ value } & \multirow[b]{2}{*}{$\mathrm{CV}(\%$} \\
\hline & FF & R33-40 & R54-61 & R33-40/54-61 & & \\
\hline Body weight (kg) & 2.12 & 2.09 & 2.22 & 2.18 & 0.279 & 4.6 \\
\hline Daily weight gain $(g / d)$ & 31.48 & 30.74 & 33.66 & 33.04 & 0.241 & 4.4 \\
\hline Daily feed intake (g/d) & 93.68 & 101.59 & 101.63 & 93.48 & 0.338 & 4.3 \\
\hline Feed:gain ratio & 2.98 & 3.39 & 3.05 & 2.84 & 0.187 & 5.2 \\
\hline
\end{tabular}

R. Bras. Zootec., v.41, n.6, p.1463-1467, 2012 
the skip-a-day system. The authors observed that there was no effect on the BW or FC of the animals, but the weekly feed intake and weight gain were greater for the animals feeding freely.

Bergaoui et al. (2008) worked with rabbits aged 35 to 77 days and subjected to feed restriction (850 and $700 \mathrm{~g} / \mathrm{kg}$ of the free feed intake). It was observed that the non-restricted animals had higher BW throughout the experimental period, but at 11 weeks of age, there was no difference in the DWG, DFI and FC between the two groups and the non-restricted rabbits. Abdel-Kafy et al. (2008) assessed rabbits fed $250 \mathrm{~g} / \mathrm{kg}$ less than the animals fed freely and observed that shortly after weaning they presented lower BW and DWG on the first week. At the end of the experimental period, no difference was observed in the performance parameters between the restricted and non-restricted animals.

Different results were obtained by Tudela \& Lebas (2006), who observed that rabbit BW and DWG decreased when the animals were subjected to $200 \mathrm{~g} / \mathrm{kg}$ restriction compared with the control treatment, which was of free feeding. However, the best FC was obtained with $400 \mathrm{~g} / \mathrm{kg}$ restriction compared with the free feeding intake. Foubert et al. (2008) also assessed $300 \mathrm{~g} / \mathrm{kg}$ feed restriction compared with free feeding intake in rabbits from 32 to 53 days of age and observed that the FC was better in the restricted rabbits, DFI $(147.4 \times 126.8 \mathrm{~g} / \mathrm{d})$, the BW $(1906 \times 1738 \mathrm{~g})$ and DWG $(46.8 \times 43.8 \mathrm{~g} / \mathrm{d})$ decreased and the FC improved $(3.11 \times 2.85)$ in the restricted rabbits.

Gidenne \& Feugier (2009) assessed growing rabbits where one group fed freely and the others had 800, 700 and $600 \mathrm{~g} / \mathrm{kg}$ of free feeding for 21 days after weaning. They were then fed ad libitum. The authors concluded that between 55 and 59 days of age, the rabbits that received $70 \%$ and $60 \%$ of the free feeding reached the same intake level as the $80 \%$ group. At 69 days of age, the feed intake in the four groups did not differ, with an average of $143.7 \mathrm{~g} / \mathrm{kg}$ per rabbit. However, during feed restriction, the BW and DWG decreased linearly with the level of restriction, but later with the re-feeding, the DWG increased linearly according to the level of restriction previously applied, but BW of the restricted rabbits remained lower than that of the nonrestricted rabbits.

There was no difference $(\mathrm{P}>0.05)$ due to feed restriction in the results of carcass weight and yield or the edible viscera relative weights (Table 2).

According to Ouhayoun (1998) carcass yield can decrease in rabbits under feed restriction due to the longer time feed is retained in the digestive tract. As a consequence, the weight of the full digestive tract is greater, thus reducing the yield at slaughter. This effect, however, was not verified statistically in the present experiment.

Some viscera, such as the liver, heart and kidneys respond rapidly to feed restriction by reducing their size and metabolic activities (Lawrence \& Fowler, 2002). The liver loses a considerable proportion of its weight at the start of restriction and, along with the heart, can be considered a labile source of protein in times of nutritional stress.

Generally, the weight of the internal organs and edible viscera such as the kidneys and liver decreases during the restriction period and increase in the re-feeding period, so there is no difference in the weights of the edible viscera of restricted and non-restricted animals at the end of the experimental period. It is assumed that in re-feeding, priority is given to the development of the internal organs that grow more quickly than the other parts of the body (Tumová et al., 2006).

Similar results were reported by Yakubu et al. (2007), who studied the effects of feed restriction (feeding for eight $8 \mathrm{~h} / \mathrm{d}$ or a skip-a-day system) on weaned rabbits for five weeks. The authors reported that there was no difference in the weight and carcass yield, relative weights of the liver, kidney and heart. Bovera et al. (2008) studied the effects of 100 and $200 \mathrm{~g} / \mathrm{kg}$ reduction in free feeding of growing rabbits on the carcass characteristics and reported that there was no difference in the hot or chilled carcass weights or in the weights of the liver and heart.

Table 2 - Carcass characteristics of growing rabbits subjected or not to feed restriction

\begin{tabular}{|c|c|c|c|c|c|c|}
\hline \multirow[t]{2}{*}{ Parameters } & \multicolumn{4}{|c|}{ Treatments } & \multirow[t]{2}{*}{$\mathrm{P}$ value } & \multirow[t]{2}{*}{ CV (\%) } \\
\hline & FF & R33-40 & R54-61 & R33-40/54-61 & & \\
\hline Carcass weight (g) & 1143 & 1116 & 1168 & 1143 & 0.117 & 5.2 \\
\hline Carcass & 541.5 & 537.4 & 530.2 & 527.3 & 0.163 & 6.2 \\
\hline Liver & 22.4 & 23.9 & 22.5 & 24.0 & 0.180 & 6.9 \\
\hline Heart & 2.40 & 2.30 & 1.90 & 1.90 & 0.064 & 1.1 \\
\hline
\end{tabular}


Bergaoui et al. (2008) studied the effects of feeding levels (1000, 850 and $700 \mathrm{~g} / \mathrm{kg}$ of free feeding intake) on the carcass characteristics of 11-week-old-rabbits and observed that the non-restricted rabbits presented lower values for CY and liver weight.

The best gross margins per rabbit (Table 3 ) were obtained with feed restriction in two periods and from 54 to 61 days of age and were 3.48 and $0.21 \%$ better for the animals sold live and sold slaughtered and cleaned, respectively, compared with the gross margins obtained with rabbits feeding freely.
This fact occurred because the animals under feed restriction at two different ages presented $28.3 \mathrm{~g} / \mathrm{kg}$ higher BW and consumed $2 \mathrm{~g} / \mathrm{kg}$ BW lower feed than the animals that fed freely. Slaughtered animals had a heavier carcass and even though they ingested more feed than the rabbits fed freely, they presented better gross margins because during the re-feeding, priority was given to recovering the organ weight. As the muscles are better formed in more mature animals, they may have felt less the effects of restriction when it was applied later.

Table 3 - Economic viability of the productive performance of growing rabbits subjected or not to feed restriction

\begin{tabular}{|c|c|c|c|c|}
\hline \multirow[t]{2}{*}{ Treatment } & \multicolumn{4}{|c|}{ Live rabbits sale } \\
\hline & BW (kg) & Live animal price $(\mathrm{R} \$)$ & Consumed feed cost (R\$) & Gross margin $(\mathrm{R} \$)$ \\
\hline $\mathrm{FF}$ & 2.12 & 15.90 & 4.14 & 11.76 \\
\hline R33-40 & 2.09 & 15.67 & 4.48 & 11.19 \\
\hline R54-61 & 2.22 & 16.65 & 4.48 & 12.17 \\
\hline \multirow[t]{3}{*}{ R33-40/54-61 } & 2.18 & 16.35 & 4.14 & 12.21 \\
\hline & \multicolumn{4}{|c|}{ Slaughtered rabbits sale } \\
\hline & CW (kg) & Carcass price ( $\mathrm{R} \$$ ) & Consumed feed cost (R\$) & Gross margin $(\mathrm{R} \$)$ \\
\hline $\mathrm{FF}$ & 1.14 & 13.68 & 4.14 & 9.54 \\
\hline R33-40 & 1.12 & 13.44 & 4.48 & 8.96 \\
\hline R54-61 & 1.17 & 14.04 & 4.48 & 9.56 \\
\hline R33-40/54-61 & 1.14 & 13.68 & 4.14 & 9.54 \\
\hline
\end{tabular}

BW - body weight; CW - carcass weight; CV - coefficient of variation.

FF - free feeding; R33-40 - feed restriction from 33 to 40 days of age; R54-61 - feed restriction from 54 to 61 days of age; R33-40/54-61 - feed restriction from 33 to 40 and from 54 to 61 days of age, respectively.

\section{Conclusions}

Feed restriction in growing rabbits at different ages can be adopted because it does not interfere negatively in the performance and carcass parameters, but feed restriction in two periods and from 54 to 61 days of age were more economically viable for sale of live and slaughtered rabbits, respectively.

\section{References}

ABDEL-KAFY, E.M.; ALI, W.A.H.; HODA, A.S. et al. Effect of short heat exposure, balanced feed restriction and acetic acid supplement at post weaning on growth and thermoregulation in growing rabbits during hot season. In: WORLD RABBIT CONGRESS, 9., 2008, Verona. Proceedings... Verona: WRSA, 2008. p.507-512.

BERGAOUI, R.; KAMMOUN, M.; OUERDIANE, K. Effects of feed restriction on the performance and carcass of growing rabbits. In: WORLD RABBIT CONGRESS, 9., 2008, Verona. Proceedings... Verona: WRSA, 2008. p.547-550.

BOVERA, F.; Di MEO, C.; MARONO, S. et al. Feed restriction during Summer: effect on rabbit growth performance. In: WORLD RABBIT SCIENCE, 9., 2008, Verona. Proceedings... Verona: WRSA, 2008. p.567-571.
CANTIER, J.; VEZINHET, A.; ROUVIER, R. et al. Allométrie de croissance chez le lapin (Oryctolagus cuniculus). 1. Principaux organes et tissues. Annales de Biologie Animale Biochimie Biophysique, v.9, p.5-29, 1969.

DALLE ZOTTE, A.; REMIGTON, H.; OUHAYOUN, J. Effect of feed rationing during post-weaning growth on meat quality, muscle energy metabolism and fibre properties of Biceps femoris muscle in the rabbits. Meat Science, v.70, p.301-305, 2005.

Di MEO, C.; BOVERA, F.; MARONO, S. et al. Effect of feed restriction on performance and feed digestibility in rabbits. Italian Journal of Animal Science, v.6, p.765-767, 2007.

FOUBERT, C.; DUPERRAY, J.; BOISOT, P. et al. Effect of feed restriction with or without free access to drinking water on performance of growing rabbits in healthy or epizootic rabbit enteropathy conditions. In: WORLD RABBIT CONGRESS, 9., 2008, Verona. Proceedings... Verona: WRSA, 2008. p.667-672.

GIDENNE, T.; FEUGIER, A. Feed restriction strategy in the growing rabbit. 1. Impact on digestion, rate of passage and microbial activity. Animal, v.3, p.501-508, 2009.

GOVAERTS, T.; ROOM, G.; BUYSE, J. et al.Early and temporary quantitative food restriction of broiler chickens. 2. Effect on allometric growth and growth hormone secretion. British Poultry Science, v.41, p.355-362, 2000.

LAWRENCE, T.L.J.; FOWLER, V.R. Growth of farm animals 2.ed. Wallingford: CAB International, 2002. p.229-254.

LEDIN, I. Effect of restricted feeding and realimentation on compensatory growth, carcass composition and organ growth in rabbit. Annales de Zootechinie, v.33, p.33-50, 1984. 
OUHAYOUN, J. Influence of the diet on rabbit meat quality. In: De BLAS, C.; WISEMAN, J. (Eds.) The nutrition of the rabbit. Wallingford: CAB International, 1998. p.177-195.

TUDELA, F.; LEBAS, F. Modalités du rationnement dês lapins en engraissement. Effets du mode de distribution de la ration quotidienne sur la vitesse de croissance, le comportement alimentaire et l'homogénéité dês poids. Cuniculture, v.33, p.21-27, 2006.

TUMOVÁ, E.; SKØIVAN, M.; SKØIVANOVÁ, V. et al. Effect of early feed restriction on growth in broiler chickens, turkeys and rabbits. Czech Journal of Animal Science, v.47, p.418-428, 2002.
TÜMOVÁ, E.; SKRIVANOVÁ, V.; SKRIVAN, M. Effect of restricted feeding time and quantitative restriction in growing rabbits. Archiv für Geflügelkunde, v.67, p.182-190, 2003.

TÜMOVÁ, E.; ZITA, L.; STOLC, L. Carcass quality in restricted and ad libitum fed rabbits. Czech Journal of Animal Science, v.51, p.214-219, 2006.

YAKUBU, A; SALAKO, A.E.; LADOKUN, A.O. et al. Effects of feed restriction on performance, carcass yield, relative organ weights and some linear body measurements of weaner rabbits. Pakistan Journal of Nutrition, v.6, p.391-396, 2007. 